\title{
The history of airborne lead and other heavy metals as revealed from sediments of Lake Vähä-Pitkusta, SW Finland
}

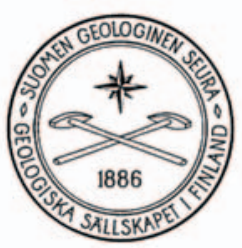

\author{
Anu Hakala* and Veli-Pekka Salonen \\ Department of Geology, P.O. Box 64, FIN-00014 University of Helsinki, Finland
}

\begin{abstract}
Lake Vähä-Pitkusta is a small, sheltered, relative deep and undisturbed lake in SW Finland. It was cored to investigate airborne deposition of heavy metals, which is not known in detail in this area. We analysed lake sediments to detect trends in the historical load of lead, cadmium, zinc, copper, nickel and vanadium and compared the deposition pattern described earlier from other parts of Europe. Sediments were dated using AMS radiocarbon and ${ }^{137} \mathrm{Cs}$-dating techniques. The results indicate that lead emissions during Roman and Medieval times reached Finland; this was detected for the first time. Medieval deposition of lead was associated with that of cadmium and zinc, suggesting their origin as long distance airborne load. Copper, nickel and vanadium deposition patterns are recent, because their strong increase of accumulation was detected only in the sediments representing the last 50 years. Most probably they originate from local pollutant sources. Overall, the results emphasize the potential value of small, sheltered headwater lakes as archives of atmospheric environmental impacts.
\end{abstract}

Key words: environmental geology, airborne pollutants, heavy metals, lead, deposition, lake sediments, pollution, Holocene, Lake Vähä-Pitkusta, Somero, Finland

\section{Introduction}

Heavy trace metals such as zinc, copper, cadmium, lead and mercury enter lakes from a variety of sources through multiple pathways. The transport may be by catchment leaching and drainage, from anthropogenic point sources or as atmospheric emissions. Atmospheric pollution caused by mercury and lead have been studied extensively since it was realized that these toxic elements accumulate in the environment by anthropogenic atmospheric emissions (e.g. Sokoloff \& Carter, 1952; Salmi, 1969; Verta et al., 1989; Norton et al., 1992).

Atmospheric pollution caused by European industrialization after ca. 1840 led to an enrichment of $\mathrm{Pb}, \mathrm{Zn}$ and $\mathrm{Cu}$ in Scottish lake sediments (Williams, 1991), but in fact the history of anthropogenic airborne metal deposition in Europe is much longer than has been observed

\footnotetext{
* Corresponding author e-mail: anu.hakala@helsinki.fi
}

in studies of lead deposition. Historical lead emissions have been studied from ice cores, peat deposits and lake sediments (Lee \& Tallis, 1973; Wolff \& Peel, 1985; Hong et al., 1994; Lobínski et al., 1994a and 1994b; Renberg et al., 1994 and 2000; Jaffe et al., 1995; Birch et al., 1996; Farmer et al., 1996; Shotyk et al., 1996; 1998; 2001 and 2002; Brännvall et al., 1997; 1999 and 2001; von Gunten et al., 1997; Heisterkamp et al., 1999; Weiss et al., 1999a and 1999b; Bindler et al., 2001; Ek \& Renberg, 2001; Ek et al., 2001; Hilfinger et al., 2001). These studies have not only provided the history of Holocenic lead deposition, but the sedimentary record also reveals the length of the anthropogenic pollution history, which was thought to start at the beginning of the Industrial Revolution, but now thought to extend further back (e.g. Murozumi et al., 1969; Hong et al., 1994; Renberg et al., 1994; Rosman et al., 1997). 
Lead concentrations in sediments display fairly uniform atmospheric deposition history throughout Europe (e.g. Renberg et al., 1994 and 2000; Farmer et al., 1996; Shotyk et al., 1998; 2001 and 2002; Brännvall et al., 1999 and 2001; Weiss et al., 1999a and 1999b; Heisterkamp et al., 1999; Ek \& Renberg, 2001; Ek et al., 2001). Lead deposited until 3000 yr $\mathrm{BP}$ is of natural origin and the concentrations are low, being normally within a range of 2 to $4 \mathrm{mg} / \mathrm{kg}$ dry matter. After this, early metallurgical activies caused a rise in the concentrations, which culminated during the prosperity of the lead mines of the Roman Empire around AD 0 (Nef, 1987). This episode of the first large-scale lead emissions ended by the decline of the Roman Empire and only the rise of Medieval industry around AD 1000 caused marked airborne lead deposition. The concentrations in European records showed a continued increase due to the Industrial Revolution, starting from $\mathrm{AD} 1800$, as a consequence of increased industry and the burning of fossil fuels, and the rate was accelerated at the dawn of the $20^{\text {th }}$ century. After World War II, lead emissions increased rapidly due to the use of leaded gasoline, and the trend culminated in the 1970s. After the gradual phasing out of leaded fuel (e.g. Hagner, 2000), lead concentrations started to decline (e.g. Moor et al., 1996).

Atmospheric lead pollution and deposition history has been thoroughly studied in Europe, especially in Scandinavia (Brännvall et al., 1997; 1999 and 2001; Renberg et al., 1994 and 2000; Ek \& Renberg, 2001; Ek et al., 2001). However, in Finland the early phases of lead pollution have not been detected. The earliest published indications of increase in lead deposition are only from the early or mid-1800s (Tolonen \& Jaakkola, 1983; Verta et al., 1989) or from the beginning of the 1900s (Virkanen et al., 1997).

On the basis of studies thus far, there is no evidence whether not or lead emissions from Roman or Medieval times reached Finland. To unravel this question, we cored a lake from Southern Finland. This lake has an exceptionally small catchment area in relation to lake size, low productivity and a stable accumulation basin, which helps to maintain the atmospheric load record. According to pollen and diatom evidence, signs of anthropogenic activities are sparse in the sediment (Hakala et al., 2004). Only the last decades have witnessed the influence of man, especially by the cottage building boom that started in the 1960s (E. Kanervo, pers. comm.). We also examined the depositional history of some other important heavy metals to compare their depositional patterns with that of lead.

\section{Study site, materials and methods}

Vähä-Pitkusta (93.3 m.a.s.l.) is a meromictic lake situated on the proximal side of the Salpausselkä III end moraine in the area of Somero, SW Finland (Fig. 1). The lake is relatively deep (max. $35 \mathrm{~m}$.) and small in size (ca. 11 ha). Its basin is built of roundish kettle depressions and it has steep shores. The catchment is about 20 ha in size and it is composed of gravel and sand. Ridges of a glaciofluvial esker rising $25 \mathrm{~m}$ above the lake with coniferous forests give shelter from the winds. The isolation of the lake from the Yoldia Sea phase of the Baltic Sea can be estimated to be somewhat younger than the age of $11500 \mathrm{cal}$. B.P. of the surrounding glaciofluvial formation (Glückert, 1978; Saarnisto $\&$ Saarinen, 2001).

The recharge of Vähä-Pitkusta is controlled by groundwater and precipitation. There are no inlets or outlets, only a small channel connecting the two Pitkusta lakes, and the retention time is 3.5-7 years (Hans Vogt, pers. comm.). The groundwater table slopes to the north, feeding Vähä-Pitkusta through its southern shores, but the outflow has decelerated due to the low permeability of the northern shores of VähäPitkusta. The lake water is clear, and oligo- to mesotrophic. There are about 30 summer cottages on the slopes of both of the Pitkusta lakes and there is one farm nearby.

For the trace metal analyses two sediment cores were obtained from the deepest part of the 


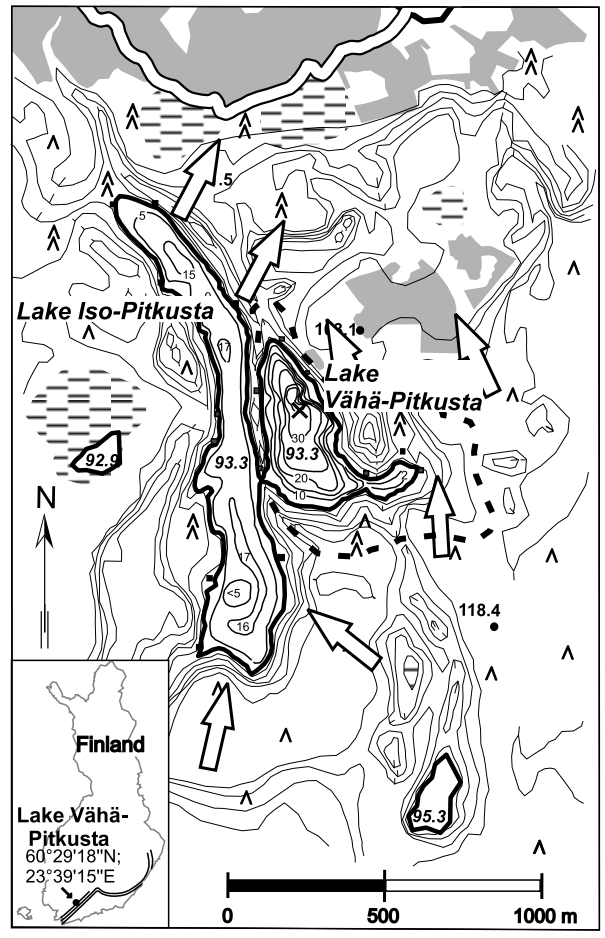

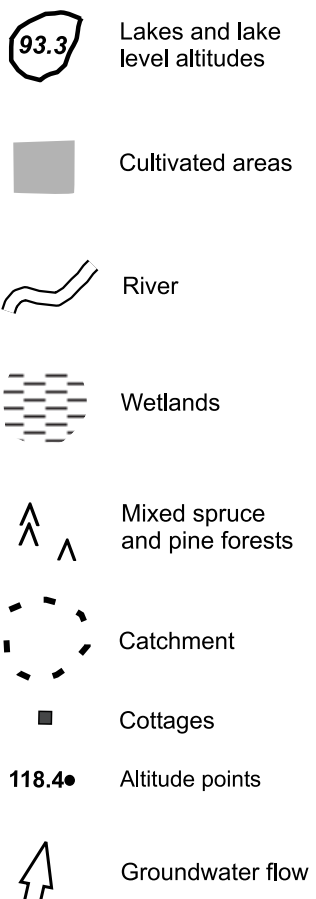

Groundwater flow
Fig. I: Location, bathymetry (Koli, 1993; unpublished material by Hans Vogt and Timo Klemelä) and the catchment area of lake Vähä-Pitkusta. The groundwater flow direction is also indicated (Achrén et al., 1998). lake; a shorter $(\mathrm{ca} .45 \mathrm{~cm}$ ) with a Limnos-type gravity corer and a longer $(\mathrm{ca} .175 \mathrm{~cm})$ with a modified Kullenbeg corer. Some compaction and possible distorting of the sediment-water interface are probable, as always in in situ sediment sampling (e.g. Baxter et al.,1991).

To analyse the history of metal deposition, the concentrations of $\mathrm{Pb}, \mathrm{Cd}, \mathrm{Zn}, \mathrm{Cu}, \mathrm{Ni}$ and $\mathrm{V}$ and LOI were determined from the core VP-1, and to double check the lead level, $\mathrm{Pb}$ was also determined from the core VP-2. The cores were subsampled into $1 \mathrm{~cm}$ and $2 \mathrm{~cm}$ sections, from which the elements were extracted with the microwave assisted solid-liquid extraction method using $\mathrm{HNO}_{3}$, and analyzed by ICP-AES (Bhatti et al., 1998). The shorter core was analysed in the Geochemical Laboratory of the University of Helsinki and the longer core in the Geolaboratory of the Geological Survey of Finland in Kuopio. The determination of loss-on-ignition was performed at the Department of Geology, University of Helsinki. The datings were carried out in the
Dating Laboratory of the University of Helsinki. Macrofossils (mainly coniferous bark and needles) from the longer core were radiocarbon dated using the AMS technique.

Age control for the topmost $10 \mathrm{~cm}$ was obtained by measuring ${ }^{137}$ Cs-activity of the sediment using a beta multicounter (Jungner, 1998). ${ }^{137} \mathrm{Cs}$ is an artificial radionuclide. Its release to the atmosphere is associated with the atmospheric testing of nuclear weapons, starting in 1952 and peaking in 1963 (Appleby, 2001). Another marker horizon for fall-out ${ }^{137} \mathrm{Cs}$ is related to the 1986 Chernobyl accident, which has been traced from many lakes in southern Finland (e.g. Kansanen et al., 1991).

\section{Results}

Figure 2 shows the radiocarbon ages (Table 1), lithostratigraphy, and loss-on-ignition (LOI). The core VP-2 is similar to the top of core VP-1. 
Table I. AMS radiocarbon dates from Lake Vähä-Pitkusta, SW Finland. Calibrated ages (I $\sigma)$ : maximum cal. age (cal. age) minimum cal. age.

\begin{tabular}{|c|c|c|c|}
\hline Lab. No. & Depth $(\mathrm{cm})$ & Age BP & Calibrated Age BP \\
\hline Hela-635 & $15-16$ & $565 \pm 40$ & $625(550) 535$ \\
\hline Hela-636 & $39-40$ & $1675 \pm 55$ & $1690(1560) 1525$ \\
\hline Hela-637 & $59-60$ & $2910 \pm 65$ & $3205(3035) 2950$ \\
\hline Hela-638 & $79-80$ & $3885 \pm 50$ & $4415(4330) 4240$ \\
\hline Hela-639 & $99-100$ & $5230 \pm 55$ & $6165(5970) 5925$ \\
\hline Hela-640 & $11-120$ & $7385 \pm 60$ & $8290(8180) 8060$ \\
\hline
\end{tabular}

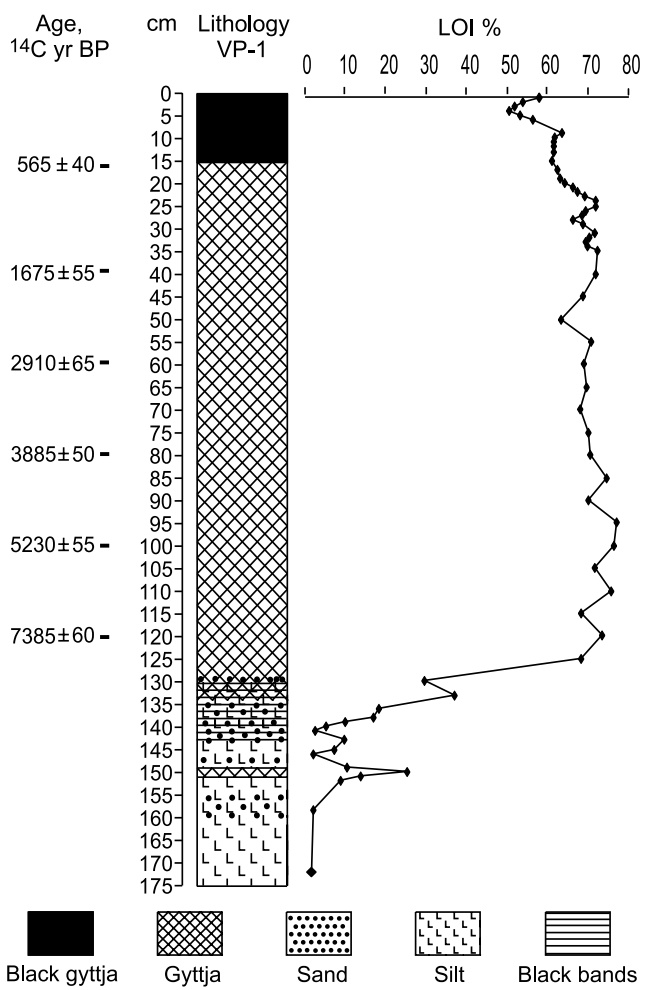

Fig. 2. Physical properties of the Vähä-Pitkusta core VP$\mathrm{I}$ and the radiocarbon age measurements.

The basal part of the longer core (VP-1) is composed of clays and silts from the Yoldia-phase of the Baltic Sea followed by a silty gyttja layer at ca. $150 \mathrm{~cm}$, representing the isolation phase, and a complicated layer of silts and sands with sulfide bands as far as $133 \mathrm{~cm}$, representing an unsteady early stage of lake development (Hakala et al., 2004). The gyttja sequence is $133 \mathrm{~cm}$ long. It consists of two units. The lower massive fine detritus gyttja is $118 \mathrm{~cm}$ thick. It has a sharp contact with the above unit; a black sulfide gyttja at the topmost ca. $15 \mathrm{~cm}$ (Fig. 2). The shorter core (VP-2) is lithologically similar to the topmost $45 \mathrm{~cm}$ portion of the longer core (VP-1).

Figure 3 displays the measured ${ }^{137} \mathrm{Cs}$-activity of the sediment core VP-1. Activity peaks at $4-5 \mathrm{~cm}$ depth from the sediment surface, where it reaches the maximum activity, $6.79 \mathrm{cpm}$. The natural backround activity level is at 1.5 to 2 cpm (Jungner, 1998).

Figure 4 gives the concentrations of $\mathrm{Pb}, \mathrm{Cd}$, $\mathrm{Zn}, \mathrm{Cu}, \mathrm{Ni}$ and $\mathrm{V}$ as a function of depth. $\mathrm{Pb}$ concentrations in cores VP-1 and VP-2 reach the limit of determination $(5 \mathrm{mg} / \mathrm{kg})$ at depths $39.5 \mathrm{~cm}$ and $54 \mathrm{~cm}$, respectively, in addition to the topmost parts of the sediment. Lead concentrations for the VP-2 core vary more than for the VP-1 core, but in general both cores represent similar decreases in concentration with depth.

The lead concentrations around the Roman Empire period are as follows: $17.3 \mathrm{mg} / \mathrm{kg}$ at $39.5 \mathrm{~cm} ; 35 \mathrm{mg} / \mathrm{kg}$ at $40.5 \mathrm{~cm}$, and $13 \mathrm{mg} / \mathrm{kg}$ at $54 \mathrm{~cm}$. Cd concentrations are below the limit of determination $(0.5 \mathrm{mg} / \mathrm{kg})$ for more than $40 \mathrm{~cm}$ in the middle part of the core (VP-1) displaying detectable concentrations in the bottom and top. $\mathrm{Zn}, \mathrm{Cu}$ and $\mathrm{Ni}$ show continuous concentrations throughout the core ( $\mathrm{Cu}$ concentration at $3.5 \mathrm{~cm}$ was discarded as an error). The $\mathrm{V}$ concentration graph is discontinuous, concentrations at $15.5 \mathrm{~cm}$ and $29.5 \mathrm{~cm}$ do not reach the limit of determination $(1 \mathrm{mg} / \mathrm{kg})$. 


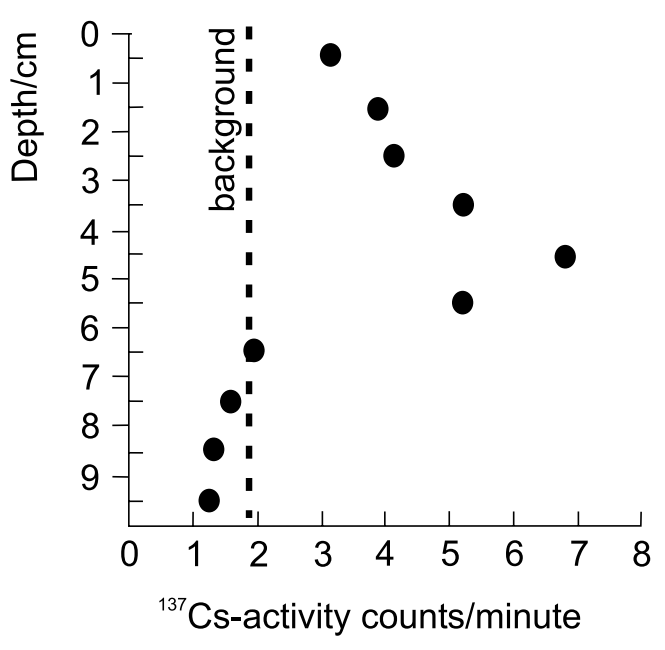

Fig. $3 .{ }^{137}$ Cs-activity of sediment of the core VP-I.

\section{Discussion}

\section{I. Dating the sediment}

The time-depth curve for the VP-1 core has been constructed using ${ }^{137} \mathrm{Cs}$ - measurements for the topmost part of the sediment, and ${ }^{14} \mathrm{C}$ determinations for its lower part (Fig. 5). The Cscurve indicates a single peak at $4-5 \mathrm{~cm}$ depth, which can indicate either fall-out associated with nuclear test maxima from 1958 to 1963 (Appleby, 2001) or with the Chernobyl accident in 1986 (Arvela et al., 1990).

The Chernobyl-peak has been measured in lakes affected by the most severe fall-out; e.g. lake Päijänne (Kansanen et al., 1991), Lake Lappajärvi (Meriläinen et al., 2000) or lake Pohjajärvi (Jungner, 1998). Lake Vähä-Pitkusta is located in SWFinland, where the fall-out was only about $10 \%$ of that received in Central Finland (Arvela et al., 1990). On this basis it is impossible to estimate whether the maximum value detected at $4-5 \mathrm{~cm}$ depth represents Chernobyl or an earlier nuclear test peak, which has been detected from e.g. lake Lovojärvi and Lake Pääjärvi, not far from Lake Vähä-Pitkusta (Jaakkola et al., 1983).

Radiocaesium is known to be mobile in lake sediments having a tendency to diffuse towards deeper parts of the sediments. However, the mobility of the radiocaesium activity in lake sed- iments seems to be significantly lower than experiments and models predict, and the peak of the activity will not move substantially (e.g. Crusius \& Anderson, 1995; Smith et al., 1998). Therefore, we consider it is safe to propose that the layers below activity peak have been accumulated before 1950s, and layers displaying increased activity levels $(6.5-0 \mathrm{~cm})$ afterwards.

\subsection{Post-depositional metal mobility}

Meromictic lakes have an incomplete circulation. The water mass is permanently stratified into two layers that do not interact with each other. Circulation is possible only within a restricted layer, which prevents overturn from top to bottom.

The basal water layer, monimolimnion, usually becomes anaerobic when connection to atmosphere is lost. Meromictic lakes provide stable accumulation environments: anaerobic monimolimnion supports only bacterial life and thus bioturbation is unsubstantial, and water turbulence is minimal due to prevented overturns. Post-depositional disturbances of the sediment interface are therefore negligible.

However, metals undergo diffusive migration in response to chemical processes in sediment. The possible migration of trace metals like $\mathrm{Pb}, \mathrm{Cd}, \mathrm{Zn}$ and $\mathrm{Cu}$ is considered to be of minor importance, especially in anaerobic conditions (e.g. Farmer, 1991; Rae \& Parker, 1996; Callender, 2000; Boyle, 2001; Alfaro-De La Torre \& Tessier, 2002). Many elements like V are more sensible for remobilization, though (e.g. Boyle, 2001). Also the elevated metal concentrations in the uppermost parts of lake sediment profiles can merely reflect depositional processes than actual accumulation. Nonetheless, the knowledge of processes affecting metals in sediments is insufficient and the models therefore frailty (Boudreau, 1999).

The time resolution in this study cannot utilize any modeling approach. The profiles of $\mathrm{Pb}$, $\mathrm{Cd}, \mathrm{Zn}, \mathrm{Cu}$ (and $\mathrm{Ni}$ ) can be rather confidently used as historical records. The profiles of $\mathrm{V}$ (and 
Fig. 4. Concentration graphs for the analyzed heavy metals $\mathrm{Pb}, \mathrm{Cd}, \mathrm{Zn}, \mathrm{Cu}, \mathrm{Ni}, \mathrm{V}$. The dashed line represents core VP-2. b.I.d. = below limit of determination.
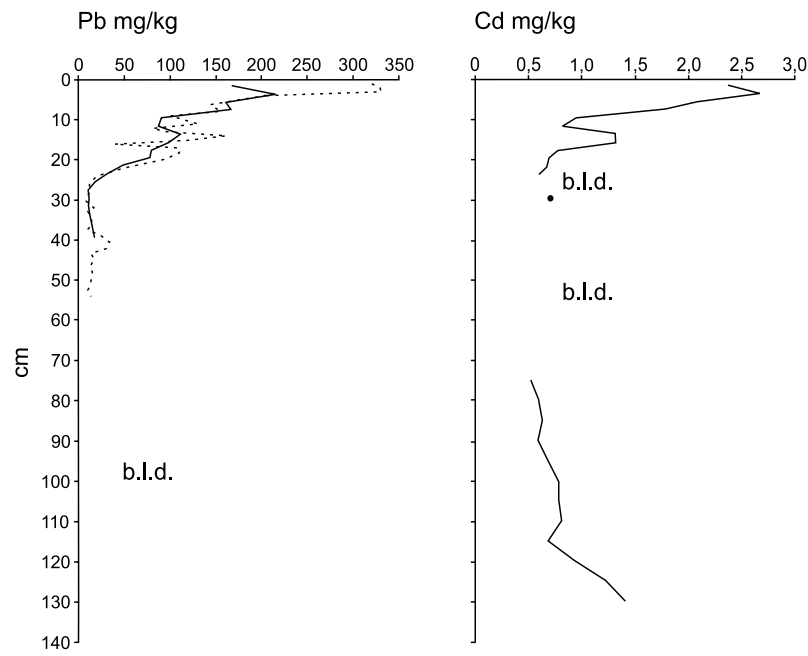

$\mathrm{Ni}$ ) must be taken with a caution. Elevated top concentrations can also be considered somewhat exaggerated, and their evidence value therefore to be of lesser degree.

\subsection{Annual accumulation of heavy metals}

Absolute concentrations are widely used in describing heavy metal load but the data they provide are not extensive. A more accurate description can be obtained from accumulation rates or metal fluxes. The accumulation rates for $\mathrm{Cd}$, $\mathrm{Zn}, \mathrm{Cu}, \mathrm{Ni}$ and $\mathrm{V}$ were calculated on the basis of the concentration results of the core VP-1, and for Pb using both cores VP-1 and VP-2 (Fig. 6). The accumulation rate has been calculated up to a depth of $6.5 \mathrm{~cm}$, where the ${ }^{14} \mathrm{C}$ curve is reliable. For the uppermost $6.5 \mathrm{~cm}$ portion, ${ }^{137} \mathrm{Cs}$ curve is used to interpret its age-depth relations.

Generally all accumulation rates for all the metals exhibit the same trend, i.e. high concentrations during the early Holocene descend to the beginning of the Common Era and rise again towards modern times. More precisely, the accumulation trends form two groups. Lead, zinc and cadmium have prominent superficial enrichments and moderate ( $\mathrm{Zn}$ and $\mathrm{Cd}$ ), or none $(\mathrm{Pb})$, basal enrichments. Copper, nickel and vanadium present strong basal enrich- ments comparable to their superficial enrichments. Additionally, $\mathrm{Cu}$ has an increased topmost concentration. Furthermore, $\mathrm{Pb}, \mathrm{Zn}$ and $\mathrm{Cd}$ show a significant rise in accumulation rates during the last millennium, but $\mathrm{Cu}, \mathrm{Ni}$ and $\mathrm{V}$ only in the uppermost $5.5 \mathrm{~cm}$ of the sediment, which according to ${ }^{137} \mathrm{Cs}$-activity represents deposits from the last 50 years.

cal. BP

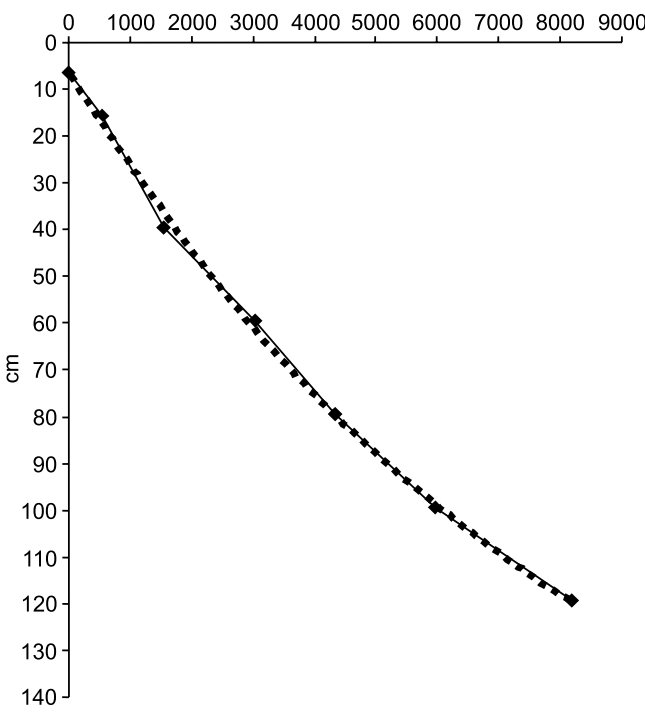

Fig. 5. Time-depth curve for the Vähä-Pitkusta core VPI was made by fitting a third order polynomical function to the data (excluding the uppermost $6.5 \mathrm{~cm}$ ). The curve indicates a stable sedimentation with an average deposition rate $0.13 \mathrm{~mm} /$ year. 

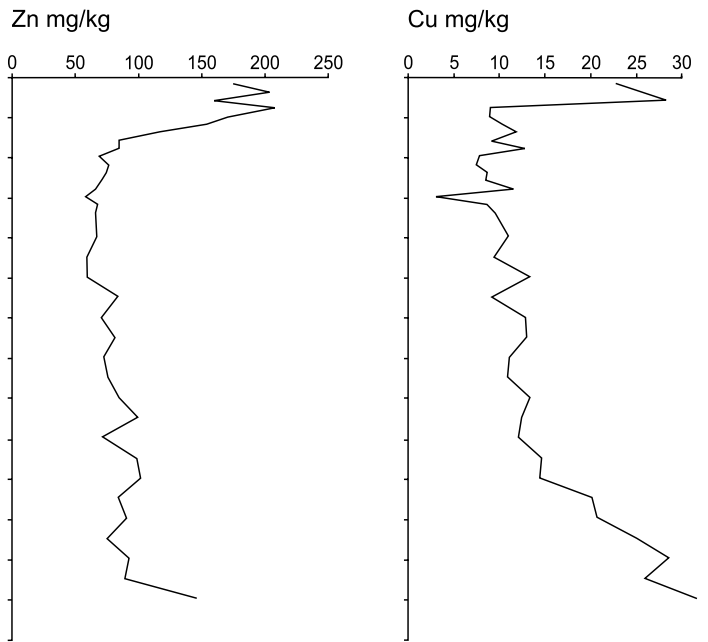

\subsection{Lake Vähä-Pitkusta sediments compared to other records}

Heavy metal concentrations in Lake VähäPitkusta are in accordance with results from small forest lakes in S Finland (Tolonen \& Jaakkola, 1983). Pb backgrounds are typically $\leq 10$ $\mathrm{mg} / \mathrm{kg}$ and surface maximums $\geq 150 \mathrm{mg} / \mathrm{kg}$ rising to $300 \mathrm{mg} / \mathrm{kg}$. Zn backgrounds are around $50 \mathrm{mg} / \mathrm{kg}$ and surface concentrations $\geq 200 \mathrm{mg} /$ $\mathrm{kg}$ rising to $370 \mathrm{mg} / \mathrm{kg}$. Cd background levels are around $0.2 \mathrm{mg} / \mathrm{kg}$ and surface enrichments $1.4-3.7 \mathrm{mg} / \mathrm{kg}$. Also Cu backgrounds are below $10 \mathrm{mg} / \mathrm{kg}$ and surface concentrations $19-48 \mathrm{mg} /$ $\mathrm{kg}$. Ni concentrations are slightly higher, backgrounds being $6.7-8.8 \mathrm{mg} / \mathrm{kg}$ and surface concentrations $16-32 \mathrm{mg} / \mathrm{kg}$, than in Lake VähäPitkusta, where minimum is $2 \mathrm{mg} / \mathrm{kg}$ and surface maximum $12 \mathrm{mg} / \mathrm{kg}$.

Results from pristine headwater lakes in $S$ Finland are similar (Verta et al., 1990): Pb surface sediment (S) 69-204 mg/kg, deep sediment (D) $2.5-43 \mathrm{mg} / \mathrm{kg} ; \mathrm{Zn}$ (S) $60-220 \mathrm{mg} / \mathrm{kg}$, (D) $12.5-170 \mathrm{mg} / \mathrm{kg}$; Cd (S) $1.0-3.4 \mathrm{mg} / \mathrm{kg}$, (D) $0.2-0.55 \mathrm{mg} / \mathrm{kg}$; Cu (S) $7.5-25 \mathrm{mg} / \mathrm{kg}$, (D) $2.7-16 \mathrm{mg} / \mathrm{kg}$; Ni (S) $6.9-19 \mathrm{mg} / \mathrm{kg}$, (D) $4.1-$ $14.5 \mathrm{mg} / \mathrm{kg}$. In northern Finland, $\mathrm{Pb}$ and $\mathrm{Cd}$ surface concentrations are clearly lower, as the other element concentrations are either on the same level or even higher than in southern Finland (Verta et al., 1990).

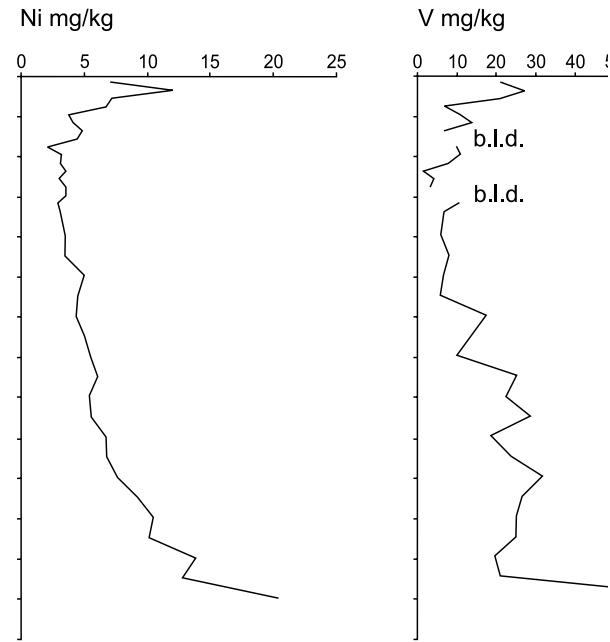

Heavy metal surface concentrations in lakes near Falun copper mines, central Sweden, are multifold to backgrounds values, which are in accordance with results from Finland (Ek \& Renberg, 2001; Ek et al., 2001; Salonen \& Tuovinen, 2001). Non-mining sites show similar enrichment trends to Lake Vähä-Pitkusta and other Finnish lakes, especially those of $\mathrm{Pb}$ (Håkanson, 1980; Renberg et al., 1994 and 2000; Brännvall et al., 1999 and 2001). In a study of 31 lakes, the Roman Empire lead concentrations increased in southern Sweden to about $20 \mathrm{mg} / \mathrm{kg}$ (range 8-41 $\mathrm{mg} / \mathrm{kg}$ ), and in northern Sweden to about $11 \mathrm{mg} /$ $\mathrm{kg}$ (range $2-27 \mathrm{mg} / \mathrm{kg}$ ). The surface sediments show concentrations typically about 100-350 $\mathrm{mg} / \mathrm{kg}$ in southern Sweden, and about 30-300 $\mathrm{mg} / \mathrm{kg}$ in N Sweden (e.g. Renberg et al., 2000; Bränvall et al., 2001).

Heavy metal load is generally higher in central parts of Europe and the United States, but to some extent $\mathrm{Pb}$ load shows a more consistent trend worldwide (e.g. Harmsworth, 1984; Williams, 1991; Norton et al., 1992; Birch et al., 1996; Farmer et al., 1996; von Gunten et al., 1997).

Accumulation rates from the 1980s in small headwater lakes all over Finland demonstrate that Lake Vähä-Pitkusta is at the higher end of the range (Verta et al., 1989 and 1990). For lakes in southern Finland, the range ends with rates similar to that of Lake Vähä-Pitkus- 
Fig 6. Accumulation rates for selected metals: $\mathrm{Pb}, \mathrm{Cd}, \mathrm{Zn}$, $\mathrm{Cu}, \mathrm{Ni}, \mathrm{V}$. The dashed line represents core VP-2. The time scale has been constructed in two parts: the uppermost three samples represent sedimentation during the last 50 years. For the lower sediments, calibrated radiocarbon years have been used. b.l.d. = below limit of determination.
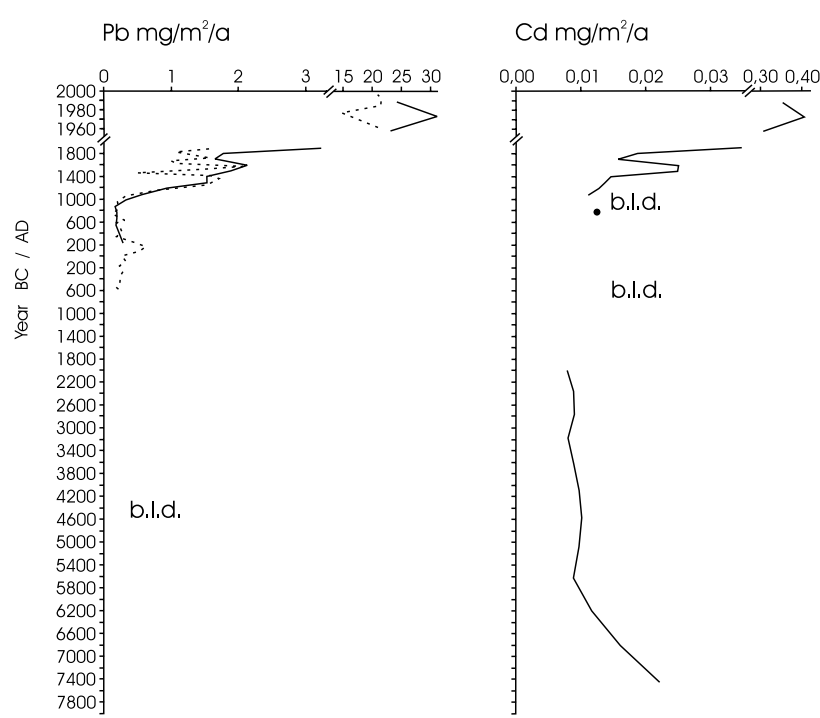

ta in the 1980s: $\mathrm{Pb} 6.2-25 \mathrm{mg} \mathrm{m}^{-2} \mathrm{a}^{-1}, \mathrm{Zn} 4.1-$ $41 \mathrm{mg} \mathrm{m}^{-2} \mathrm{a}^{-1}$, Cd 0.098-0.47 $\mathrm{mg} \mathrm{m}^{-2} \mathrm{a}^{-1}$, and $\mathrm{Cu} 1.3-4.2 \mathrm{mg} \mathrm{m}^{-2} \mathrm{a}^{-1}$ (Verta et al., 1989), $\mathrm{Ni}$ about $0.5-3 \mathrm{mg} \mathrm{m}^{-2} \mathrm{a}^{-1}$ and $\mathrm{V}$ about $1.2-3.6 \mathrm{mg}$ $\mathrm{m}^{-2} \mathrm{a}^{-1}$ (Verta et al., 1990). Results from other lakes in southern Finland indicate accumulation rates within the aforementioned range, but in the upper end, suggesting heavy metal deposition in Lake Vähä-Pitkusta is rather typical for S Finland (e.g. Tolonen \& Jaakkola, 1983; Virkanen et al., 1997).

On one hand, the pattern is rather universal when remote areas and headwater lakes are concerned; accumulation rates in lowalkalinity lakes in the United States largely fit into the range determined for Finnish lakes. However, there are some outliers beyond the upper end of the range (Norton et al., 1992). On the other hand, areas of high human activity and population, like central parts of Europe and USA, suffer from much greater loading, as discussed earlier.

\subsection{Record of heavy metal deposition in Lake Vähä-Pitkusta}

Accumulation rates of $\mathrm{Pb}, \mathrm{Cd}$, and $\mathrm{Zn}$ have the same pattern of change, as well as those of $\mathrm{Cu}$ and $\mathrm{Ni}$. This is in accordance with the data indicating that the main source of $\mathrm{Pb}, \mathrm{Cd}$ and $\mathrm{Zn}$ is long-distance transport, while $\mathrm{Cu}$ and $\mathrm{Ni}$ are mainly from regional emissions (Verta et al., 1989).

Permanent settlement in the area originated in the late $15^{\text {th }}$ century, but only in the late $18^{\text {th }}$ century the population started to grow. The lakes and the surrounding moor were a few kilometers to the south of a village (Oja, 1949; von Hertzen, 1987). The historical evidence together with biostratigraphical results, which indicate weak anthropogenic activity in the area (Hakala et al., 2004), suggest negligible local emissions before the last century, especially before the last 50 years during which there was a rapid emergence of summer residences and human activity.

The early Holocene enrichments are results of the unstable conditions during the meltdown of the dead ice block and the isolation of the lake (Hakala et al., 2004). At first, minerogenic input was extensive (Fig. 2), and erosion and leaching took place. After this, lake development continued relatively steadily (Hakala et al., 2004), which is also visible in the accumulation rates. About 2500-3000 cal. BP, a possible lake level rise and/or increased surface runoff took place, which probably resulted from a change to a cooler and moister climate (Hakala et al., 2004).

Rapid increases in $\mathrm{Pb}$ and $\mathrm{Cd}$ accumulations and a slower rise in $\mathrm{Zn}$, began a millennium ago, 

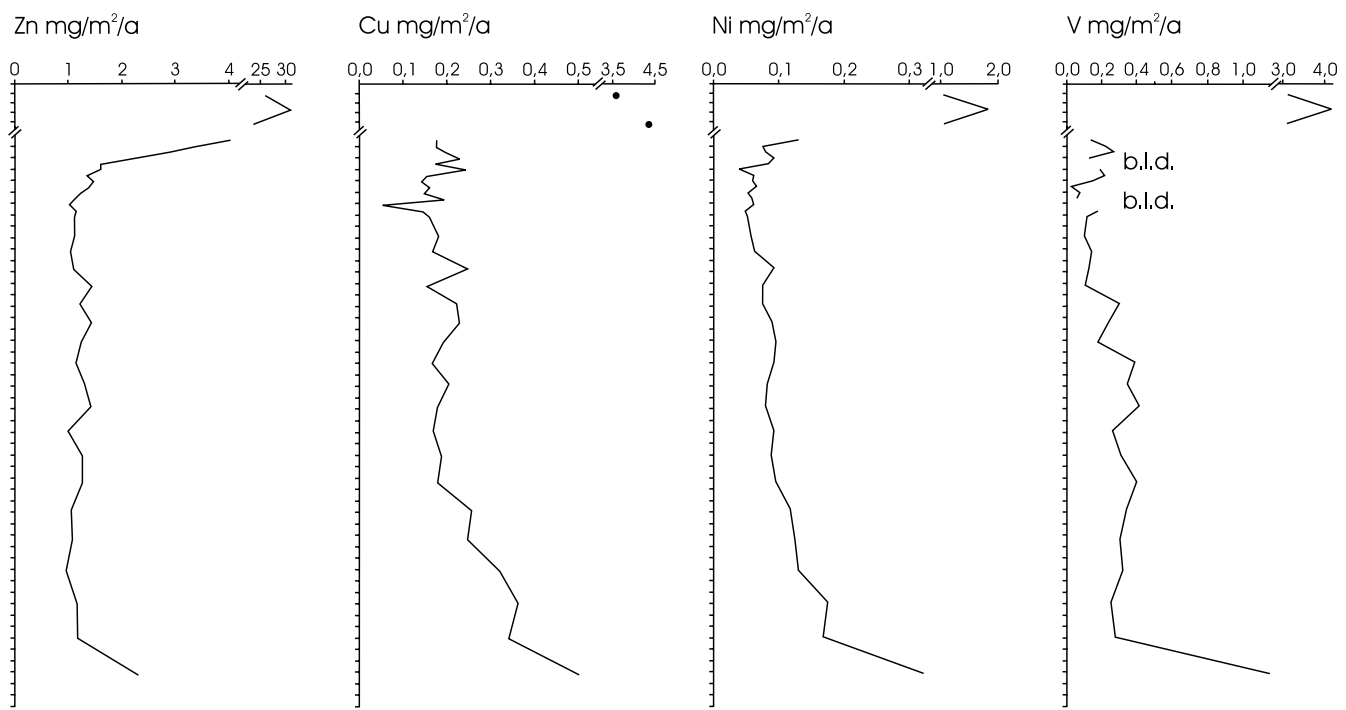

simultaneously with the medieval expansion of metallurgical activities in Central Europe and Great Britain (Nef, 1987) and during a time of tranquillity in the lake surroundings. A new economic boom started in the $15^{\text {th }}$ century causing another increase in the accumulations rates, which culminated in the $16^{\text {th }}$ century, followed by a decline. These changes demonstrate the significance of long-distance transport in Lake Vähä-Pitkusta. Accumulation in the last century is a mix of long-and short-distance anthropogenic emissions.

$\mathrm{Cu}$ and $\mathrm{V}$ accumulation rates did not rise until the Second World War. Ni deposition started to increase slightly as early as in the early $20^{\text {th }}$ century, but the acceleration took place simultaneously with copper and vanadium. In Finland, the tremendous change in pollution of regional origin is largely due to the war reparations paid to the Soviet Union. These were paid mostly in ships and machinery, i.e. products of the metal industry. Since the Finnish pre-war industry was underdeveloped, the war reparations motivated large-scale innovations and investments into industry (e.g. Holmström, 1986; Vehviläinen, 1992). Therefore, the most distinct feature is the prominent metal enrichment of upper sediment over the last 50 years in accumulation rates, emphasizing the magnitude of industrial evolution and

the modern anthropogenic impact on the environment.

\subsection{Lead deposition history in Lake Vähä-Pitkusta}

Through the Holocenic history of Lake VähäPitkusta, lead concentrations were below the limit of determination of the analyzer until ca. $2500 \mathrm{cal}$. BP. This was shortly after the introduction of coinage when word lead production had risen from ca. 160 annual tons to almost 10 000 tons per year (Settle \& Patterson, 1980). In Swedish lake sediments, ${ }^{206} \mathrm{~Pb} /{ }^{207} \mathrm{~Pb}$ isotope ratios changed concurrently (Brännval et al., 1999 and 2001; Renberg et al., 2000), indicating that the excess lead originated from atmospheric lead pollution.

The first peak, shortly after AD 0 , is visible widely in various media; e.g. lake sediments in Sweden (Renberg et al., 1994 and 2000), peat in Switzerland (Shotyk et al., 1996 and 2002), and glacier ice in Greenland (Hong et al., 1994; Rosman et al., 1997). During the short but intense high point of the Roman Empire, the world lead production reached 80000 tons per year (Settle \& Patterson, 1980). In the second and third centuries, there were metallurgical activities in almost all countries conquered by the Romans. Roman mining was rather uneconomic and the 
level of know-how low. Furthermore, the value of mining was controversial. All this led to abandonment of mines when readily accessible ores were largely exhausted (Nef, 1987). With the fall of the Roman Empire, lead production and consequently atmospheric lead declined to the preceding level, and therefore the accumulation recorded in the sediment declined.

With the increased medieval population, farming, trade and industry, i.e. the whole economy, mining and metallurgical activities started to expand in the $10^{\text {th }}$ and $11^{\text {th }}$ centuries. There were several mines in the Alps, and prospecting for ore spread throughout Europe (Nef, 1987). As mining and metallurgical activities were associated with general prosperity, the consequence of the Black Death, which wiped out 25-45\% of the European population and paralyzed the remaining population in the $14^{\text {th }}$ century, was a sharp decline in mining and atmospheric emissions (Gottfried, 1983; Nef, 1987). The Black Death took place at the time of optimum demand for bullion and metals for guns. This stimulated the rehabilitation, new inventions and techniques, and soon after the Black Death, mining and metallurgical activities experienced general expansion (Gottfried, 1983).

During the transition from the Middle Ages to modern time, extraordinarily rich ores were found in South and Central America. Mining of American metals and their delivery to Europe were cheaper than local production, which led the European mining industry into economic depression. In the $17^{\text {th }}$ century, the slump was deep (Nef, 1987), and its reflection is clearly visible in the lead accumulation rate in Lake VähäPitkusta.

Not until the dawn of the Industrial Revolution did the world lead production reach the level of the Romans (Settle \& Patterson, 1980). Since the $19^{\text {th }}$ century lead accumulation rates have been rising, but the major peak was not experienced until after the Second World War. Recent accumulation rates are descending, mostly due to banning leaded fuel. The change in concentration rates is more drastic, e.g. in Swedish lake sediments lead concentrations will soon be at the level of those in the $13^{\text {th }}$ century (Renberg et al., 2000).

\section{Conclusions}

The profiles of $\mathrm{Pb}, \mathrm{Cd}, \mathrm{Zn}, \mathrm{Cu}$ (and $\mathrm{Ni}$ ) can be rather confidently used as historical records. They show that lead emissions during Roman and Medieval times reached Finland. Medieval airborne lead was associated with cadmium and zinc, suggesting their origin as long distance airborne load. Copper, nickel and vanadium deposition patterns are recent, because their strong increase of accumulation was detected only in the sediments representing the last 50 years. Most probably they, as well as $\mathrm{Pb}, \mathrm{Cd}$, and $\mathrm{Zn}$, originate from strongly developing industry and traffic in Finland after the Word War II.

\section{Acknowledgements}

We wish to thank H. Vogt, T. Klemelä, H. Hyvärinen, A. Miettinen, A. Vuorinen, T. Vaahtojärvi, H. Jungner, J. Karhu, M. Kelokaski, and A. Meadows. Thanks for the comments of J. Meriläinen and an anonymous referee of the journal. Financial support from Academy of Finland (Grant 202981), Finnish Graduate School in Geology, Alfred Kordelin Foundation, the Finnish Cultural Foundation, the Oskar Öflund Foundation and the Sohlberg's Delegation of the Finnish Society of Sciences and Letters.

Editorial handling: Timo Tarvainen

\section{References}

Achrén, F., Aaltonen, H. \& Virtanen, A., 1998. Katselmuskirja: Salon kaupungin, Halikon kunnan ja Perttelin kunnan hakemus pohjaveden ottamiseksi Herakkaanlähteen vedenottamoista Someron kaupungissa ja Kaskistonnummen vedenottamosta Kiikalan kunnassa. Vesioikeuden diaarinumero 94101, $34 \mathrm{p}$.

Alfaro-De La Torre, Ma. C. \& Tessier, A., 2002. Cadmium deposition and mobility in the sediments of an acidic oligotrophic lake. Geochimica et Cosmochimica Acta 66, 3549-3562.

Appleby, P.G., 2001. Chronostratigraphic techniques in recent sediments. In: Last, W. M. \& Smol, J. P. (eds.) Tracking environmental change using lake sediments. Volume 1: Basin analysis, coring, and chronological techniques. Kluwer Academic Publishers, Dorchrecht, 171-203.

Arvela, H., Markkanen, M. \& Lemmelä, H., 1990. Mobile survey of environmental gamma radiation and fall-out levels in Finland after the Chernobyl accident. Radiation Protection Dosimetry 32, 177-184. 
Baxter, M.S., Farmer, J.G., McKinley, I.G., Swan, D.S. \& Jack, W., 1981. Evidence of the unsuitability of gravity coring for collecting sediment in pollution and sedimentation rate studies. Environmental Science and Technology 15, 843-846.

Bhatti, T.M., Vuorinen, A., Lehtinen, M. \& Tuovinen, O.H., 1998. Dissolution of uraninite in acid solution. Journal of Chemical Technology \& Biotechnology 73, 259-263.

Bindler, R., Renberg, I., Anderson, N.J., Appleby, P.G., Emteryd, O. \& Boyle, J., 2001. Pb isotope ratios of lake sediments in West Greenland: inferences on pollution sources. Atmospheric Environment 35, 46754685.

Birch, L., Hanselmann, K.W. \& Bachofen, R., 1996. Heavy metal conservation in Lake Cadagno sediments: historical records of anthropogenic emissions in a meromictic alpinen lake. Water Research 30, 679-687.

Boyle, J., 2001. Redox remobilization and the heavy metal record in lake sediments: a modeling approach. Journal of Paleolimnologia 26, 423-431.

Boudreau, B.P., 1999. Metals and models: Diagenetic modeling in freshwater lacustrine sediments. Journal of Paleolimnologia 22, 227-251.

Brännvall, M.-L., Bindler, R., Emteryd, O., Nilsson, M. \& Renberg, I., 1997. Stable isotope and concentration records of atmospheric lead pollution in peat and lake sediments in Sweden. Water, Air, and Soil Pollution 100, 243-252.

Brännvall, M.-L., Bindler, R., Renberg, I., Emteryd, O., Bartnicki, J. \& Billstöm, K., 1999. The medieval metal industry was the cradle of modern large-scale atmospheric lead pollution in northern Europe. Environmental Science \& Technology 33, 4391-4395.

Brännvall, M.-L., Bindler, R., Emteryd, O. \& Renberg, I., 2001. Four thousand years of atmospheric lead pollution in northern Europe: a summary from Swedish lake sediments. Journal of Paleolimnology 25, 421-435.

Callender, E., 2000. Geochemical effects of rapid sedimentation in aquatic systems - minimal diagenesis and the preservation of historical metal signatures. Journal of Paleolimnologia 23, 243-260.

Crusius, J. \& Anderson, R.F., 1995. Evaluating the mobility of ${ }^{137} \mathrm{Cs},{ }^{239+240} \mathrm{Pu}$ and ${ }^{210} \mathrm{~Pb}$ from their distributions in laminated lake sediements. Journal of Paleolimnology 13, 119-141.

Ek, A.S. \& Renberg, I., 2001. Heavy metal pollution and lake acidity changes caused by one thousand years of copper mining at Falun, central Sweden. Journal of Paleolimnology 26, 89-107.

Ek, A.S., Löfgren, S., Bergholm, J. \& Qvarfort, U., 2001. Environmental effects of one thousand years of copper production at Falun, central Sweden. Ambio 30, 96-103.

Farmer, J.G., 1991. The perturbation of historical records in aquatic sediments. Envrionmental Geochemistry and Health 13, 76-83.

Farmer, J.G., Eades, L. J., Mackenzie, A.B., Kirika, A. \& Bailey-Watts, T.E., 1996. Stable lead isotope record of lead pollution in Loch Lomond sediments since 1630 A.D. Environmental Science \& Technology 30, 3080-3083.

Glückert, G., 1978. Das Deltakomplex von Kiikalannummi am 3. Salpausselkä in Südwestfinnland. Publications of the Department of Quaternary Geology, University of Turku 35, 1-26.
Gottfried, R.S., 1983. The Black Death. Natural and human disaster in Medieval Europe. Robert Hale, London, 203 p.

Hagner, C., 2000. European regulations to reduce lead emissions from automobiles - did they have an economic impact on the German gasoline and automobile markets? Regional Environmental Change 1, 135-151.

Hakala, A., Sarmaja-Korjonen, K. \& Miettinen, A., 2004. The origin and evolution of Lake Vähä-Pitkusta, SW Finland - a multi proxy study of a meromictic lake. Hydrobiologia 527, 85-97.

Håkanson, L., 1980. An ecological risk index for aquatic pollution control. A sedimentological approach. Water Research 14, 975-1001.

Harmsworth, R.V., 1984. Längsee: A geochemical history of meromixis. Hydrobiologia 108, 219-231.

Hilfinger, M.F., Mullins, H.T., Burnett, A. \& Kirby, M.E., 2001. A 2500 year sediment record from Fayetteville Green Lake, New York: evidence for anthropogenic impacts and historic isotope shift. Journal of Paleolimnology 26, 293-305.

Heisterkamp, M, van de Velde, K., Ferrari, C., Boutron, C.F. \& Adams F.C., 1999. Present century record of organolead pollution in high altitude Alpine snow. Environmental Science \& Technology 33, 4416-4421.

Holmström, L., 1986. Maksoimme velkaa. Sotakorvauspäiviä ja vähän öitäkin. Insinööritieto $\mathrm{Oy,} 208$ p.

Hong, S., Candelone, J.-P., Patterson, C.C. \& Boutron, C.F., 1994. Greenland ice evidence of hemispheric lead pollution two millennia ago by Greek and Roman civilizations. Science 265, 1841-1843.

Jaakkola, T., Tolonen, K., Huttunen, P. \& Leskinen, S., 1983. The use of fallout ${ }^{137} \mathrm{Cs}$ and ${ }^{239},{ }^{240} \mathrm{Pu}$ for dating of lake sediments. Hydrobiologia 103, 15-19.

Jaffe, D., Cerundolo, B., Rickers, J., Stolzberg, R. \& Baklanov, A., 1995. Deposition of sulfate and heavy metals on the Kola Pensinsula. Science of the Total Environment 160/161, 127-134.

Jungner, H., 1998. Tracing the Chernobyl fall-out peak in Finnish lake sediments in order to obtain a good time marker. Dating of sediments and determination of sedimentation rate, STUK report series A145,116-119.

Kansanen, P.H., Jaakkola, T., Seppälä, J., Hökkä, M., Kulmala, S. \& Suutarinen, R., 1991. Chernobyl fallout nuclides used as tracers of sedimentation and sediment mixing in four Finnish lakes. International symposium on the use of isotope techniques in water resources development. IAEA-SM-319/10, 1-8.

Koli, L., 1993. Someron vedet. Oy Amanita Production Ltd, Somero, $132 \mathrm{p}$.

Lee, J.A. \& Tallis, J.H., 1973. Regional and historical aspects of lead pollution in Britain. Nature 245, 216 218.

Lobínski, R., Boutron, C.F., Candelone, J-P., Hong, S., Szpunar-Lobínski, J. \& Adams, F.C., 1994a. Present century snow core record of organolead pollution in Greenland. Environmental Science \& Technology 28, 1467-1471.

Lobínski, R., Boutron, C. F., Candelone, J-P., Hong, S., Szpunar-Lobínski, J. \& Adams, F. C., 1994b. Northern hemispheric organic lead emissions in fresh Greenland snow. Environmental Science \& Technology 28, 1459-1466. 
Meriläinen, J.J., Hynynen, J., Teppo, A., Palomäki, A., Granberg, K. \& Reinikainen, P., 2000. Importance of diffuse nutrient loading and lake level changes to the eutrophication of an originally oligotrophic boreal lake: a palaeolimnological diatom and chironomid analysis. Journal of Paleolimnology 24, 251-270.

Moor, H.C., Schaller, T. \& Sturm, M., 1996. Recent changes in stable lead isotope ratios in sediments of Lake Zug, Switzerland. Environmental Science \& Technology 30, 2928-2933.

Murozumi, M., Chow, T.J. \& Patterson, C., 1969. Chemical concentrations of pollutant lead aerosols, terrestrial dusts and sea salts in Greenland and Antarctic snow strata. Geochimica et Cosmochimica Acta 33, 1247-1294.

Nef, J.V., 1987. Mining and metallurgy in medieval civilization. In: Postan, M. M \& Miller, E. (eds.) The Cambridge Economic History of Europe. II. Trade and Industry in the Middle Ages. Cambridge University Press, 693-761.

Norton, S.A., Bienert, Jr. R.W., Binford, M.W. \& Kahl, J.S., 1992. Stratigraphy of total metals in PIRLA sediment cores. Journal of Paleolimnology 7, 191-214.

Oja, A., 1949. Someron historia vuoteen 1940. In: Aaltonen, E. (ed.) Someron historia I. Forssan kirjapaino Oy, Forssa, 7-64.

Rae, J.E. \& Parker, A., 1996. Techniques for validating the historic record of lake sediments. A demonstration of their use in the English Lake District. Applied Geochemistry 11, 211-215.

Renberg, I., Wik Persson, M. \& Emteryd, O., 1994. Preindustrial atmospheric lead contamination detected in Swedish lake sediments. Nature 386, 323-326.

Renberg, I., Bränvall, M.-L., Bindler, R. \& Emteryd, O., 2000. Atmospheric lead pollution history during four millennia (2000 BC to 2000 AD) in Sweden. Ambio 29, 150-156.

Rosman, K. J. R., Chisholm, W., Hong, S., Candelone, J.-P. \& Boutron, C. F., 1997. Lead from Carthaginian and Roman Spanish mines isotopically identified in Greenland ice dated from 600 B.C. to 300 A.D. Environmental Science \& Technology 31, 3413-3416.

Saarnisto, M. \& Saarinen, T., 2001. Deglaciation chronology of the Scandinavian Ice Sheet from the Lake Onega Basin to the Salpausselkä End Moraines. Global and Planetary Change 31, 387-405.

Salmi, M., 1969. Tienvarsien saastuminen Suomessa. Terra $81,229-233$.

Salonen, V-P. \& Tuovinen, N., 2001. Orijärvi: a lake impacted by acid mine drainage. In: Lehtonen, $\mathrm{T}$., Salminen, J.-P. \& Pihlaja, K. (eds) Proceedings of the Fifth Finnish Conference of Environmental Sciences, Turku May 18.-19. 2001,. Finnish Society for Environmental Sciences, University of Turku, p. 62-64

Settle, D.M. \& Patterson, C.C.,1980. Lead in Albacore: Guide to lead pollution in Americans. Science 207, 1167-1176.

Shotyk, W., Cheburkin, A.K., Appleby, P.G., Fankhauser, A. \& Kramers, J.D., 1996. Two thousand years of atmospheric arsenic, antimony, and lead deposition record in an ombrotrophic peat bog profile, Jura Mountains, Switzerland. Earth and Planetary Science Letters 145, E1-E7.

Shotyk, W., Weiss, D., Appleby, P.G., Cheburkin, A.K., Frei, R., Gloor, M., Kramers, J.D., Reese, S. \& Van Der Knaap, W.O., 1998. History of atmospheric lead deposition since 12,370 14C yr BP from a peat bog, Jura Mountains, Switzerland. Science 281, $1635-1640$
Shotyk, W., Weiss, D., Kramers, J.D., Frei, R., Cheburkin, A.K., Gloor, M. \& Reese, S., 2001. Geochemistry of the peat bog at Etand de la Gruère, Jura Mountains, Switzerland, and its record of atmospheric $\mathrm{Pb}$ and lithogenic trace metals ( $\mathrm{Sc}, \mathrm{Ti}, \mathrm{Y}, \mathrm{Zr}$, and REE) since 12,370 14C yr BP. Geochimica et Cosmochimica Acta 65, 2337-2360.

Shotyk, W., Weiss, D., Heisterkamp, M., Cheburkin A.K., Appleby, P.G. \& Adams, F.C., 2002. New peat bog record of atmospheric lead pollution in Switzerland: $\mathrm{Pb}$ concentrations, enrichment factors, isotopic composition, and organolead species. Environmental Science \& Technology 36, 3893-3900.

Smith, J.T., Ireland, D.G., Comans, R.N.J. \& Nolan, L., 1998. The mobility of radiocaesium in lake sediment and implications for dating studies. STUK report series A-145, 76-93.

Sokoloff, V.P. \& Carter, G.F., 1952. Time and Trace Metals in Archaeological Sites. Science 116, 1-5.

Tolonen, K. \& Jaakkola, T., 1983. History of lake acidification and air pollution studied on sediments in South Finland. Annales Botanici Fennici 20, 57-78

Vehviläinen, O., 1992. Liittoutuneiden valvontakomission armoilla. Sotakorvaukset. Teoksessa: Hietanen, S., Seppinen, I., Vehviläinen, O. \& Vuorenmaa, A. (toim.) Kansakunta sodassa. 3. Kuilun yli. Valtion painatuskeskus, Helsinki, 218-220

Verta, M., Tolonen, K. \& Simola, H., 1989. History of heavy metal pollution in Finland as recorded by lake sediments. The Science of the Total Environment $87 /$ $88,1-18$.

Verta, M., Mannio, J., Irvonen, P., Hirvi, J.-P., Järvinen, O. \& Piepponen, S., 1990. Trace metals in Finnish headwater lakes - effects of acidification and airborne load. In: Kauppi, P., Anttila, P. \& Kenttämies, K. (eds.) Acidification in Finland, Springer-Verlag, Berlin and Heidelberg, 883-908.

Virkanen, J., Korhola, A., Tikkanen, M. \& Blom, T., 1997. Recent environmental changes in a naturally acidic rocky lake in southern Finland, as reflected in its sediment geochemistry and biostratigraphy. Journal of Paleolimnology 17, 191-213.

von Gunten, H.R., Sturm, M. \& Moser, R.N., 1997. 200-year record of metals in lake sediments and natural backround concentrations. Environmental Science \& Technology 31, 2193-2197.

von Hertzen, E., 1987. Kiikalan historiallinen aika. Pitäjän yhteisö syntyy. Teoksessa: Sarvas, A. \& von Hetzen, E. (toim.) Kiikalan historia. Gummerus Oy, Jyväskylä, 59-151.

Weiss, D., Shotyk, W., Kramers, J.D. \& Gloor, M. 1999a. Sphagnum mosses as archives of recent and past atmospheric lead deposition in Switzerland. Atmospheric. Environment 33, 3751-3763.

Weiss, D., Shotyk, W., Appleby, P. G., Kramers, J. D. \& Cheburkin, A. K., 1999b. Atmospheric Pb deposition since the industrial revolution recorded by five Swiss peat profiles: enrichment factors, fluxes, isotopic composition, and sources. Environmental Science \& Technology 33, 1340-1352.

Williams, T.M., 1991. A sedimentary record of the deposition of heavy metals and magnetic oxides in the Loch Dee basin, Galloway, Scotland, since AD 1500. Holocene 1-2, 142-150.

Wolff, E. W. \& Peel, D. A., 1985. The record of global pollution in polar snow and ice. Nature 313 , $535-540$. 